\title{
White Cell Counts, CRP and Appendicitis - Is There A Role for Pre- Operative Blood Tests? A Cohort Study
}

\author{
Adam Tucker $^{1^{*}}$, K Sloan ${ }^{1}$, lan Gartsin ${ }^{1}$ and Regina Verghis ${ }^{2}$ \\ ${ }^{1}$ Ward C6, Antrim Area Hospital, Bush Road, Antrim, BT41 2RL, United Kingdom \\ ${ }^{2}$ CRSC, Grosvenor Road, Belfast, BT12 6BA, United Kingdom
}

\section{Introduction}

Acute appendicitis is one of the most common emergency surgical admissions, with a lifetime prevalence of one in seven presentations [1]. Appendicectomy accounts for approximately $10 \%$ of all emergency abdominal procedures [2,3]. The diagnosis of appendicitis is purely based on history, clinical examination and some basic laboratory investigations. However, the definitive diagnosis is made on histology.

The Alverado scoring system is a clinical scoring system that can be applied to a patient to support a clinical diagnosis of appendicitis. It is based on 6 clinical features and 2 laboratory investigations, namely the white cell count (WCC) and neutrophil shift. It does not take into account the CRP levels.

A score of 5 or 6 is compatible with the clinical diagnosis of acute appendicitis. However, histology remains the gold standard for definitive diagnosis.

Various papers have advocated the use of the Alverado scoring system in supporting the diagnosis of acute appendicitis, but few papers have looked at WCC and CRP levels as comparative markers.

Most of the literature involves studies in children, which have resulted in conflicting conclusions. Many have concluded that there is no significance in the WCC or CRP levels in suspected acute appendicitis [4], others imply that together they enhance the predictive value of appendicitis [5-7]. Some authors suggest that CRP simply serves to assess the risk of developing complications from acute appendicitis e.g., perforation or abscess formation [8,9]. Some studies advocate the use of radiological imaging (ultrasound or CT) in order to increase the positive predictive value of diagnosing acute appendicitis pre-operatively, but supportive evidence is anecdotal at best $[10,11]$.

This study aims to assess the clinical usage of pre-operative WCC and CRP levels, and their relationship, if any, in patients with suspected appendicitis.

\section{Patients and Methods}

A retrospective review of a single year of surgical cases was performed from 1 January 2009 to $31^{\text {st }}$ December 2009. The list of patients was obtained from the histopathology laboratory of all appendix specimens recorded. All patients had their demographics and pre-operative WCC and CRP levels recorded by two of the study authors (AT and KS). At the time of collation of data on pre-operative WCC and CRP levels, neither author knew the definitive histopathology. Once all blood tests were obtained, the definitive histological result was recorded for each patient who had complete pre-operative blood tests (i.e., a recorded WCC and CRP).

Histological findings were grouped as normal, "acute" (acutely inflamed), "complicated" (perforated, gangrenous or necrotic), and "other" (helminth infection, active malignancy, chronic inflammation). Only the acute and complicated groups were included in the study for statistical analysis. Each patient within these groups then had their pre-operative WCC and CRP levels recorded alongside their definitive histological diagnosis. Upper limits for normal laboratory test ranges were used for WCC (normal range $4-14 / \mathrm{mm}^{3}$ ) and CRP (normal value $<7 \mathrm{mg} / \mathrm{l}$ ) levels. This was utilized because an arbitrary cut off number holds no value as no consensus exists between clinicians on a clinically significant raised level for either.

From the data, sensitivity and specificity, positive and negative predictive values were calculated. A multinomial logistic model was used to compare the population groups in order to calculate relative risk ratios (RR). Statistical analysis of the data was performed using Stata/IC 10.1 for Windows, and GraphPad Prism version 5.0. A p value $<0.05$ was considered to be statistically significant for all statistical analyses.

\section{Results}

A total of 343 patients were identified from pathology records. A total of sixteen of these were excluded; five in the "acute" group, 1 in the "complicated" group, and 6 in the "other" group had no preoperative blood tests, and 4 were excluded due to blood testing errors. The remaining 327 patients were comprised of 188 males (57.49\%) and 139 females (42.51\%). Mean age was 27.99 years ( $\mathrm{SD} \pm 17.04$ years), with a range from 5 to 92 years. The patients were categorized into groups as follows; acute $\left(\mathrm{n}_{\mathrm{A}}=192\right)$, complicated $\left(\mathrm{n}_{\mathrm{C}}=49\right)$, other $\left(\mathrm{n}_{\mathrm{O}}=25\right)$ and normal $\left(\mathrm{n}_{\mathrm{N}}=61\right)$. Data for each group is further summarized in Table 1A.

Breakdown of diagnoses in the "other" group is detailed in Table $1 \mathrm{~B}$, and any incidental findings in the "normal" group are detailed in Table 1C.

The total population normal reference ranges for WCC was 4-14 $\times$ $10^{9}$ cells/lof blood. Normal range for CRP levels was less than $7 \mathrm{mg} /$ liter.

Firstly, we will consider the whole population in whom surgery was performed for suspected appendicitis. WCC levels ranged from $4-27 \times 10^{9}$ cells/l. An abnormal WCC was significantly associated with a histological diagnosis of appendicitis $(\mathrm{P}<0.0001)$. CRP levels ranged from $1-538 \mathrm{mg} / \mathrm{l}$. The presence of an elevated CRP was also significantly associated with appendicitis $(\mathrm{p}=0.013)$, albeit less than WCC.

*Corresponding author: Adam Tucker, Surgical Trainee, Ward C6, Antrim Area Hospital, Bush Road, Antrim, BT41 2RL, United Kingdom, Tel: +44 (0)28 94424000; Fax : +44 (0) 90635436; E-mail: atuc@hotmail.com

Received February 03, 2015; Accepted March 16, 2015; Published March 23 2015

Citation: Tucker A, Sloan K, Gartsin I, Verghis R (2015) White Cell Counts, CRP and Appendicitis - Is There A Role for Pre-Operative Blood Tests? A Cohort Study. $\mathrm{J}$ Health Med Informat 6: 185. doi:10.4172/2157-7420.1000185

Copyright: $\odot 2015$ Tucker A, et al. This is an open-access article distributed under the terms of the Creative Commons Attribution License, which permits unrestricted use, distribution, and reproduction in any medium, provided the original author and source are credited. 
Citation: Tucker A, Sloan K, Gartsin I, Verghis R (2015) White Cell Counts, CRP and Appendicitis - Is There A Role for Pre-Operative Blood Tests? A Cohort Study. J Health Med Informat 6: 185. doi:10.4172/2157-7420.1000185

Page 2 of 6

\begin{tabular}{|c|c|c|c|c|c|}
\hline & Acute Appendix & Complicated & Other & Normal & Total \\
\hline & $118(61.46 \%)$ & $37(75.51 \%)$ & $13(52 \%)$ & $20(32.79 \%)$ & $188(57.49 \%)$ \\
\hline & $74(38.54 \%)$ & $12(24.49 \%)$ & $12(48 \%)$ & $41(67.21 \%)$ & $139(42.51 \%)$ \\
\hline $\mathrm{N}$ & 192 & 49 & 25 & 61 & 327 \\
\hline Mean (SD) & $26.51(16.21)$ & $32.53(19.64)$ & $38.32(20.31)$ & $24.77(13.74)$ & $27.99(17.04)$ \\
\hline Inter-quartile range & 14 to 36 & 17 to 46 & 23 to 51 & 14 to 30 & 15 to 37 \\
\hline Range & 5 to 92 & 7 to 82 & 8 to 83 & 8 to 60 & 5 to 92 \\
\hline $\mathrm{N}$ & 182 & 47 & 23 & 59 & 311 \\
\hline Mean (SD) & $13.94(4.36)$ & $15.13(4.70)$ & $10.40(3.60)$ & $10.82(4.31)$ & $13.27(4.62)$ \\
\hline Inter-quartile range & $11.1-17$ & $12.1-18.5$ & $7.6-12.1$ & $7.8-14$ & $9.7-16.5$ \\
\hline Range & $4.4-26.4$ & $5.9-27$ & $5.6-18$ & $4-19.8$ & $4-27$ \\
\hline $\mathrm{N}$ & 185 & 48 & 23 & 58 & 314 \\
\hline Mean (SD) & $56.53(86.49)$ & $129.75(123.87)$ & $51.22(51.99)$ & $50.83(99.83)$ & $66.28(97.17)$ \\
\hline Inter-quartile range & 5 to 64 & 44 to 203.5 & 3 to 100 & 1 to 54 & 5 to 85 \\
\hline Range & 1 to 453 & 1 to 508 & 1 to 143 & 1 to 538 & 1 to 538 \\
\hline
\end{tabular}

Table 1A: Summary statistics for gender, age, white cell count, C-reactive protein.

\begin{tabular}{|c|c|}
\hline Other diagnosis was & N \\
\hline Adhesions/band adhesion & 6 \\
\hline Primary intra-abdominal malignancy & 5 \\
\hline Subacute inflammation & 5 \\
\hline Chronic & 3 \\
\hline Faecolith & 2 \\
\hline Inflammatory bowel disease & 1 \\
\hline Endometriosis & 1 \\
\hline Reactive & 1 \\
\hline Abscess & 1 \\
\hline Total & 25 \\
\hline
\end{tabular}

Table 1B: Summary of diagnoses listed as "other" based on final histology report. These patients were not included in the statistical analysis.

\begin{tabular}{|c|c|}
\hline $\begin{array}{c}\text { Incidental finding in "normal" patient } \\
\text { was }\end{array}$ & $\mathbf{N}$ \\
\hline Faecoliths & 6 \\
\hline Helminth/pinworm infection & 5 \\
\hline meckels & 2 \\
\hline SBP & 1 \\
\hline Fibrosis & 1 \\
\hline Adhesion & 1 \\
\hline Nothing i.e., truly normal & 61 \\
\hline
\end{tabular}

Table 1C: Summary of incidental findings in the "normal" group. Again, these were not included in the final analysis.

\begin{tabular}{|c|c|c|c|}
\hline Predictors & Acute & Complicated & Other \\
\hline Male & $2.76(0.92) \mathrm{a}^{* *}$ & $5.88(2.76)^{* *}$ & $3.04(1.62)^{*}$ \\
\hline Age & $1.01(0.01)$ & $1.03(0.01)^{*}$ & $1.05(0.02)^{* *}$ \\
\hline White cell count & $1.18(0.05)^{* *}$ & $1.26(0.07)^{* *}$ & $0.97(0.06)$ \\
\hline Abnormal CRP & $2.12(0.72)^{*}$ & $8.26(5.12)^{* *}$ & $1.62(0.94)$ \\
\hline
\end{tabular}

'Normal' category is considered as the reference

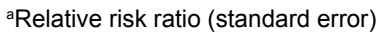

"p<0.05, " $p<0.01,{ }^{* * *} p<0.001$

Table 2: Multinomial logistic regression model demonstrating the relative risk ratios (RRR) for each variable by study subgroup when compared to the 'normal' population

Figures 1 and 2 are box plots with 95\% confidence limits for WCC and CRP levels in each of the four categorical groups.

\section{Acute Appendicitis}

Acute appendicitis was seen in 192 patients, with a male predominance $(61.46 \%)$. Mean age was $26.51 \pm 16.21$ years (range 5-92). WCC ranged from 4.4-26.4 cells/l, with a mean of $13.94 \pm 4.36$ cells/l (Table 1A). Sensitivity of an elevated WCC in acute appendicitis was 0.66 , and specificity 0.49 . The presence of a raised WCC in acute appendicitis was statistically significant $(\mathrm{p}=0.03)$ (Table 2$)$. ReceiverOperator Characteristics (ROC) curve analysis revealed that a WCC $>14.05$ conveyed a sensitivity of 0.48 and specificity of 0.76 with a likelihood ratio of acute appendicitis of 2.06 compared to a normal reference group (Table 3). Area under the curve (AUC) analysis was statistically significant $(\mathrm{p}<0.0001)$ (Figure 3$)$.

CRP levels in acute appendicitis ranged from 1-453 mg/l, with a mean of $56.53 \pm 86.49 \mathrm{mg} / \mathrm{l}$ (Table 1A). Sensitivity of an elevated CRP in acute appendicitis was 0.59 , and specificity 0.36 . The presence of a raised CRP was not statistically significant $(\mathrm{p}=0.05)$ (Table 4$)$. ROC analysis demonstrated a level $>7.05$ conveyed a sensitivity of $0.70 \%$, specificity of 0.50 and a likelihood ratio of 1.39. AUC analysis was statistically significant $(\mathrm{p}<0.01)$.

Multinomial logistic regression models demonstrated the relative risk ratio (RR) for WCC and CRP levels in acute appendicitis. Risk factors included male gender (RR of 2.76; $p<0.01$ ), a unit rise in WCC (RR 1.18; $\mathrm{p}<0.001)$ and an abnormal CRP (RR 2.12; $\mathrm{p}<0.05)$.

\section{Complicated Appendicitis}

Complicated appendicitis was seen in 49 patients, again with a male preponderance $(75.51 \%)$. Mean age was $32.53 \pm 19.64$ years with a range of 7-82 years. WCC ranged from 5.9-27 cells/l, with a mean of $15.13 \pm 4.70$ cells/l (Table 1A). Sensitivity of an elevated WCC in complicated appendicitis was 0.21 , and specificity 0.89 . The presence of a raised WCC in complicated appendicitis was statistically significant $(\mathrm{p}=0.03)$. ROC analysis demonstrated a WCC level $>13.95$ conveyed a sensitivity of 0.60 , specificity of 0.62 with a likelihood ratio of 2.34 compared to a normal reference group. AUC analysis was statistically significant $(\mathrm{P}<0.0001)$.

CRP levels in complicated appendicitis ranged from 1 to $508 \mathrm{mg} / \mathrm{l}$, with a mean of $129.75 \pm 123.87 \mathrm{mg} / \mathrm{l}$. Sensitivity of an abnormal CRP in complicated appendicitis was 0.20 , and specificity 0.95 - a highly specific marker of complicated disease. The presence of a raised CRP for complicated appendicitis was statistically significant $(\mathrm{p}<0.01)$. ROC analysis demonstrated that a level $>7$ conveyed sensitivity of 


\begin{tabular}{|l|l|l|l|l|}
\hline $\begin{array}{l}\text { Abnormal } \\
\text { CRP Level } \\
\text { (n) }\end{array}$ & Acute & Complicated & Other & Normal \\
\cline { 2 - 5 } & $130(70.27 \%)$ & $44(91.67 \%)$ & $17(73.91 \%)$ & $29(50 \%)$ \\
\hline
\end{tabular}

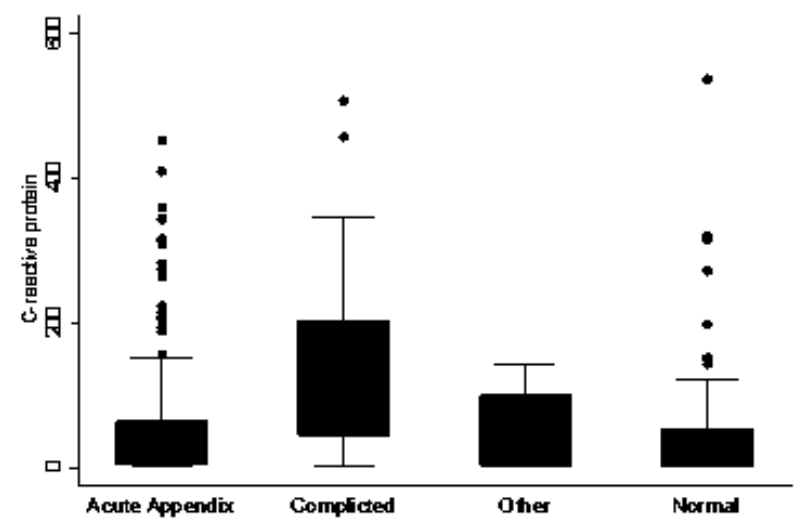

Figure 1: Abnormal CRP levels and Appendicitis box and whisker plot indicating the minimum, maximum and mean values of CRP for each subgroup with $95 \%$ confidence limits.

NB The plots out with the limits are values which lie outside the $95 \% \mathrm{Cl}$ The figure demonstrates that an elevated CRP is more often observed in complicated appendicitis.

\begin{tabular}{|l|l|l|l|l|}
\hline $\begin{array}{l}\text { Abnormal } \\
\text { WCC Level }\end{array}$ & Acute & Complicated & Other & Normal \\
\cline { 2 - 5 }$(\mathbf{n})$ & $139(76.37 \%)$ & $39(82.98 \%)$ & $\begin{array}{l}(43.48 \%) \\
25(42.37 \%)\end{array}$ \\
\hline
\end{tabular}

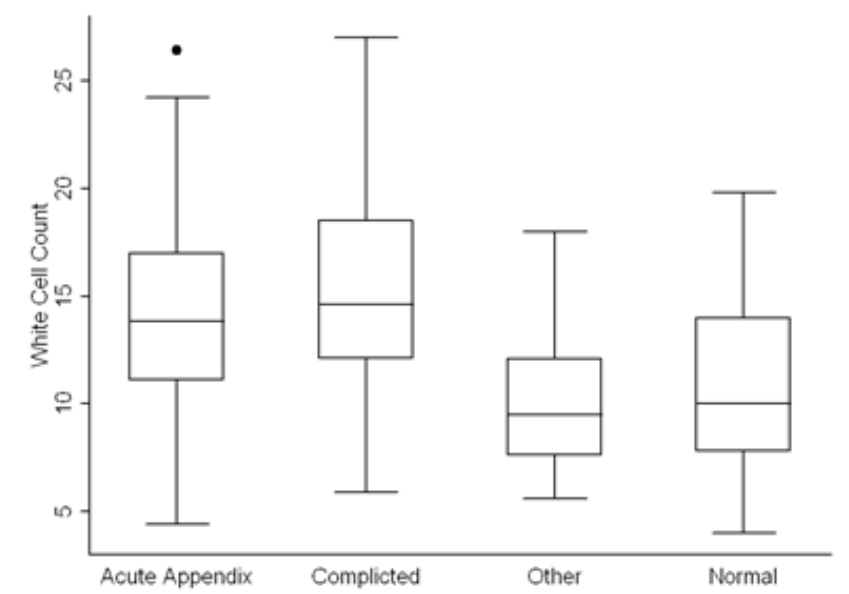

Figure 2: Abnormal WCC levels and Appendicitis box and whisker plot indicating the minimum, maximum and mean values of WCC for each subgroup with $95 \%$ confidence limits. The figure demonstrates a raised WCC for both acute and complicated appendicitis.

0.92 , specificity of 0.50 and a likelihood ratio of 1.83 for complicated appendicitis. AUC was highly significant $(\mathrm{p}<0.0001)$.

Multinomial regression analysis revealed a similar RR (1.26; $\mathrm{p}<0.001)$ to acute appendicitis. However, a much greater RR was found if the patients were male (RR 5.88; $\mathrm{p}<0.001)$ with an abnormally elevated CRP (RR 8.26; $\mathrm{p}<0.01)$.

Full statistical results are further categorized in Tables 1A, 2-5.

ROC analysis revealed that WCC was highly statistically significant indicator of both acute and complicated disease. However, elevated
CRP levels are more significant indicator of potential complicated disease.

Considering the overall population, surgery for suspected appendicitis was performed correctly in $73.4 \%$ of all cases. However, $41 / 139$ (29.5\%) of the female population, compared to $20 / 188$ (10.6\%) of the male population, who underwent surgery, had a normal appendix at definitive histology.

\section{Discussion}

Delayed diagnosis of appendicitis has an adverse effect on morbidity and mortality. The uses of clinical adjuncts, such as serum inflammatory markers, are aimed at minimizing this risk.

CRP was first discovered by Tillett and Francis in 1930. Their work demonstrated the presence of CRP in the serum of patients with pneumococcus. The substance was named CRP because of its reaction to the capsular polysaccharide of the pneumococcus [12]. It is synthesized by the liver in response to interleukins and cytokines produced by macrophages. Structurally it is a pentraxin calcium dependent ligand [13]. CRP binds to phosphocholine which is expressed on dead or dying cells, as well as some bacteria. This leads to the subsequent activation of the complement system via the classical pathway. Levels rapidly increase in response to the acute insult, peaking at 48 hours, with a constant half-life of approximately 19 hours. The sole determinant of circulating CRP concentration is the synthesis rate [14]. Therefore, removal of the stimulus, quickly results in CRP levels returning to normal. Measurement of CRP levels acts as a screen for infectious and inflammatory processes. The myriad of causes reflect its poor specificity for a single pathological entity, however the presence of an elevated level is suggestive of complicated appendicitis [15]. Therefore, a raised CRP can powerfully influence management when considered in the greater clinical context, but it is not an ideal diagnostic tool [16,17]. One Meta-analysis has shown that CRP sensitivity and specificity tends to vary significantly as a diagnostic tool for appendicitis [18]. CRP levels have been shown to be a more reliable indicator of the severity of the inflammatory process, with higher levels occurring in more advanced disease [19], with CRP sensitivity for acute and complicated appendicitis increasing 48-72 hours after the onset of symptoms [20].

Leucocytes are derived from haemopoietic stem cells. The most common type is the myeloid lineage polymorphonuclear (PMN) leucocyte, or neutrophil, accounting for up to $70 \%$ of the total leucocyte count in blood [21]. Neutrophils have an important role in host defence against bacterial of fungal infection. This is usually as a result of various chemical mediators such as the pro-inflammatory interleukins and tumour necrosis factor alpha [21]. They are usually the first responders in the systemic cascade evoked by microbial infection, such as in appendicitis.

Delayed diagnosis of appendicitis results in poorer outcomes with increased morbidity. Many studies have been designed to investigate the association between abnormal blood serum results and appendicitis. The majority of papers have been conducted in children [4-11].

It is generally accepted that the morbidity associated with delayed diagnosis of appendicitis, with subsequent abscess formation, far outweighs the morbidity of a negative appendicectomy [16]. Postoperative morbidity is greatly increased for those with complicated appendicitis, especially in elderly males. One study reports a morbidity of $28.4 \%$ compared to $4.7 \%$ in perforated and acute appendicitis respectively [22]. Raised WCC and CRP levels have been found to be 
Citation: Tucker A, Sloan K, Gartsin I, Verghis R (2015) White Cell Counts, CRP and Appendicitis - Is There A Role for Pre-Operative Blood Tests? A Cohort Study. J Health Med Informat 6: 185. doi:10.4172/2157-7420.1000185

Page 4 of 6

\begin{tabular}{|c|c|c|c|}
\hline & Value & Sensitivity \% & Specificity \% \\
\hline Acute & & & \\
\hline WCC $\left(\right.$ cells $\left./ \mathrm{mm}^{3}\right)$ & $>14.05$ & 48.9 & 76.27 \\
\hline CRP $(\mathrm{mg} / \mathrm{l})$ & $>7.5$ & 69.73 & 50 \\
\hline Complicated & & & \\
\hline WCC $\left(\right.$ cells $\left./ \mathrm{mm}^{3}\right)$ & $>13.95$ & 59.57 & \\
\hline CRP $(\mathrm{mg} / \mathrm{l})$ & $>7$ & 91.67 & 61.56 \\
\hline
\end{tabular}

Table 3: Receiver-operator characteristic (ROC) curve derived figures showing sensitivity, specificity and likelihood ratio for both acute and complicated patient groups with respect to the pre-operatively blood test. Normal Reference ranges were used as an arbitrary cut-off point holds no clinical value unless widely accepted by clinicians.

\begin{tabular}{|c|c|c|c|c|c|c|c|c|c|}
\hline & \multicolumn{3}{|c|}{ WCC } & \multicolumn{3}{|c|}{ CRP } & \multicolumn{3}{|c|}{ Combination test } \\
\hline & Acute & Comp & Either & Acute & Comp & Either & Acute & Comp & Either \\
\hline $\begin{array}{c}\text { Sensitivity } \\
(95 \% \mathrm{Cl})\end{array}$ & $\begin{array}{c}0.66(0.59- \\
0.72)\end{array}$ & $\begin{array}{c}0.21(0.16- \\
0.25)\end{array}$ & $\begin{array}{c}0.89(0.85- \\
0.92)\end{array}$ & $\begin{array}{c}0.59(0.56- \\
0.62)\end{array}$ & $\begin{array}{c}0.20(0.18- \\
0.21)\end{array}$ & $\begin{array}{c}0.79(0.76- \\
0.83)\end{array}$ & $\begin{array}{c}0.83(0.76- \\
0.90)\end{array}$ & $\begin{array}{c}0.70(0.59- \\
0.75)\end{array}$ & $\begin{array}{c}0.79(0.73- \\
0.84)\end{array}$ \\
\hline $\begin{array}{l}\text { Specificity } \\
(95 \% \mathrm{Cl})\end{array}$ & $\begin{array}{c}0.47(0.42- \\
0.52)\end{array}$ & $\begin{array}{c}0.89(0.85- \\
0.923)\end{array}$ & $\begin{array}{c}0.42(0.35- \\
0.49)\end{array}$ & $\begin{array}{c}0.36(0.27- \\
0.46)\end{array}$ & $\begin{array}{c}0.95(0.89- \\
0.98)\end{array}$ & $\begin{array}{c}0.35(0.27- \\
0.44)\end{array}$ & $\begin{array}{c}0.53(0.42- \\
0.62)\end{array}$ & $\begin{array}{c}0.93(0.80- \\
0.99)\end{array}$ & $\begin{array}{c}0.68(0.59- \\
0.75)\end{array}$ \\
\hline X2 (Yates) & 4.57 & 4.95 & 37.17 & 0.46 & 9.47 & 6.11 & 2.93 & 9.97 & 39.24 \\
\hline$p$ value & 0.03 & 0.03 & $<0.0001$ & 0.50 & $<0.01$ & 0.01 & 0.09 & $<0.01$ & $<0.0001$ \\
\hline
\end{tabular}

Table 4: Summary of contingency table outcomes for WCC and CRP. WCC was found to be a statistically significant indicator of acute disease presence, whilst CRP was not. Whilst not specific tests, both reflected a high sensitivity for presence of the disease with the WCC being more sensitive than a rise in CRP levels. Combination testing, whereby at least one of the variables was positive, increased sensitivity and specificity in both groups. Chi-squared $\left(\mathrm{X}^{2}\right)$ analysis indicated the WCC to be statistically significant

\begin{tabular}{|c|c|c|c|}
\hline & Acute WCC Results & Acute CRP Results & Complicated WCC Results \\
\hline Area & 0.70 & 0.62 & 0.75 \\
\hline Std. Error & 0.04 & 0.05 & 0.79 \\
\hline 95\% confidence interval & $0.62-0.78$ & $0.53-0.71$ & 0.05 \\
\hline P value & $<0.0001$ & $<0.01$ & $0.65-0.84$ \\
\hline
\end{tabular}

Table 5: ROC data for the ROC curves.

\section{ROC of Acute WCC versus Normal}

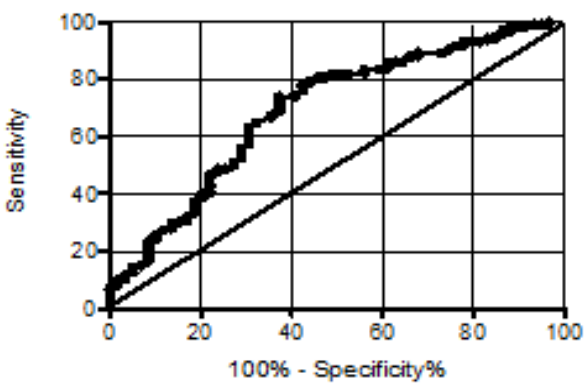

ROC of Acute CRP versus Normal

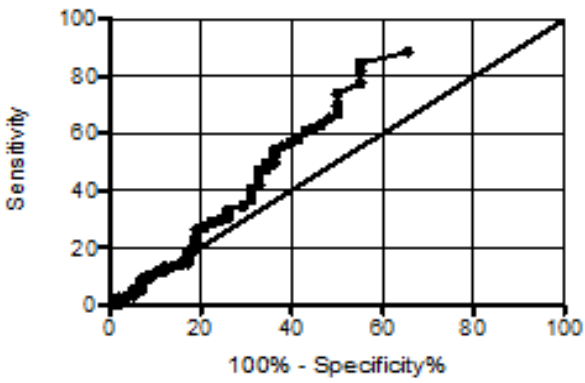

ROC of Complicated WCC versus Normal

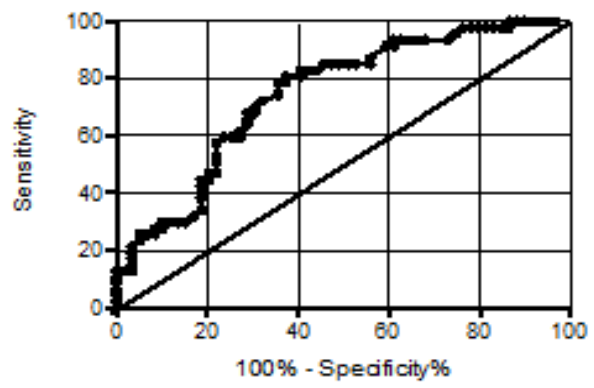

ROC of Complicated CRP versus Normal

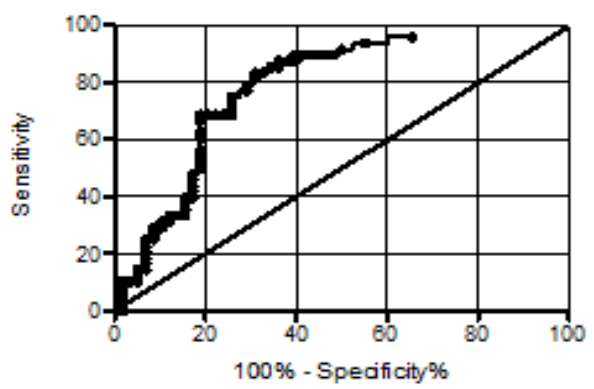

Figure 3: ROC curves for WCC and CRP levels in both acute and complicated appendicitis. 
an indicator of complicated appendicitis in other reported literature $[15,22,23,24-26]$, and our results are comparable. Most studies advocate the use of pre-operative serology tests as an adjunct to history and examination findings in the diagnosis of the condition [27]. Definitive diagnosis however, remains a histological one.

Our data suggests that the pre-operative WCC is a good indicator of appendicitis, in both acute and complicated cases. This was found to be statistically significant $(\mathrm{p}<0.0001)$ but did not convey an increase in the RR to the same extent as CRP levels. The CRP level is however, a better indicator of complicated appendicitis. It was also shown to have a profound effect on the RR for complicated appendicitis with a RR of $8.26(\mathrm{p}<0.01)$

Operative management of appendicitis can be either via a laparoscopic or open approach. Often the decision rests with operating surgeon's preference and experience. Increased complications have been shown to occur as a result of laparoscopic surgery; especially in complicated disease [20]. The results provided from this study may assist surgeons in planning their operative approach, favouring an open approach in patients with significantly elevated CRP levels, suggestive of perforation, gangrene or necrosis of the appendix.

We acknowledge that the specificity for both WCC and CRP was low. This may be due to the number of false positive surgeries performed. These were mainly in females and may be attributable to other causes of abdominal pain such as ovarian pathology, which may be confused for appendicitis. We found that 1 in 3 surgical interventions in females was negative for appendicitis and therefore we advocate consideration of other pathological causes for abdominal pain in this population. We also suggest that these individuals may benefit from radiological investigation such as ultrasound scanning pre-operatively to assess the condition of the appendix, or from diagnostic laparoscopy before embarking on definitive surgery. The RR was found to be increased in the male population for both acute and complicated appendicitis. This may be attributable to the number of false positive interventions in the female population. Interestingly, the other group also had an elevated RR (3.04) for male population as demonstrated in Table 2. Whist this was not part of the primary aims of the study, the exact reasons for this are unclear. The diagnoses for "other" causes are all inflammatory, and it may be that some of these diagnoses are more prevalent in a male population - however this is mere author speculation.

\section{Conclusion}

We, the authors, conclude that appendicitis remains largely a retrospective diagnosis. However, there is a role for pre-operative WCC and CRP levels in aiding clinical diagnosis. The WCC was a more significant indicator of acute appendicitis, but elevated CRP levels were more indicative of perforated, gangrenous or necrotic appendicitis. This may in turn, influence the surgical approach favoured by the surgeon.

This study also demonstrated the difficulty in diagnosing appendicitis in females of child bearing age. More false positive surgeries were performed in females, with one in three females having unnecessary surgery. This may favour the use of radiological investigations to enhance pre-operative diagnosis in this population, and the need for consideration of a laparoscopic approach for appendicectomy in the first instance.

\section{References}

1. Khan I, Ur Rehman A (2005) Application of the Alvarado Scoring System in Diagnosis of Acute Appendicitis. J Ayub Med coll Abbottabad 17: 41-44.
2. Pal KM, Khan A (1998) Appendicitis: A Continuing Challenge. J Pak Med Assoc 48: 189-192.

3. Kumar V, Cotran RS, Robbins SL (1992) Robbins Basic Pathology (5thedn.) WB Saunders, United States.

4. Yang HR, Wang YC, Chung PK, Chen WK, Jeng LB, et al. (2005) Role of Leukocyte Count, Neutrophil Percentage, and C-Reactive Protein in the Diagnosis of Acute Appendicitis in the Elderly. Am Surg 1: 344 - 347.

5. Beltran MA, Almonacid J, Vicenio A, Gutierrez J, Cruces KS, et al. (2007) Predictive Value of White Blood Cell Count and C-Reactive Protein in Children with Appendicitis. J Paediatr Surg 42:1208-1214.

6. Kwan KY, Nagar AL (2010) Diagnosing Pediatric Appendicitis: Usefulness of Laboratory Markers. Am J Emerg Med 28: 1009-1015.

7. Khan MN, Davie E, Irshad K (2004) The Role of White Cell Count and C-reactive protein in the Diagnosis of Acute Appendicitis. J Ayub Med Coll Abbottabad 16 171-179.

8. Anielski R, Kusnier- Cabala B, Szafraniec K (2010) An Evaluation of the Utility of Additional Tests in the Preoperative Diagnostics of Acute Appendicitis. Lagenbecks Arch Surg 395: 1061-1068.

9. Gronroos JM, Forsstrom JJ, Irjala K, Nevalainen TJ (1994) Phospholipase A2, C-Reactive Protein, And White Blood Cell Count in the Diagnosis of Acute Appendicitis. Clin Chem 40: 1757-1760.

10. Kessler N, Cyteval C, Gallix B, Lesnik A, Blayac PM, et al. (2004) Appendicitis: Evaluation of Sensitivity, Specificity, and Predictive Values of US, Doppler US, and Laboratory Findings. Radiology 230: 472-478.

11. Tepel J, Sommerfeld A, Klomp HJ, Kapischke M, Eggert A, et al. (2004) Prospective Evaluation of Diagnostic Modalities in Suspected Acute Appendicitis. Lagenbecks Arch Surg 389: 219-224.

12. Tillett WS, Francis T (1930) Serological Reaction in Pneumonia with a Nonprotein Somatic fraction of Pneumococcus. J Exp Med 52: 561-571.

13. Pepys MB, Hirchfield GM (2003) C-Reactive Protein: A Critical update. K Clin Invest 111: 1805-1812.

14. Vingushin DM, Pepys MB, Hawkins PN (1993) Metabolic and Scintigraphic Studies or Radioiodiated Human C-Reactive Protein in Health and Disease. J Clin Invest 91: 1351-1357.

15. Shindoh J, Niwa H, Kawai K, Ohata K, Ishihara Y, et al. (2011) Diagnostic Power of Inflammatory Markers in Predicting Severity of Appendicitis. Hepatogastroenterology 58: 2003-2006

16. Jess P, Bjerregaard B, Brynitz S, Holst-CJ, Kalaja E, et al. (1981) Acute Appendicitis. Prospective Trial Concerning Diagnostic Accuracy and Complications. Am J Surg 141: 232-234.

17. Broker ME, Van Lieshout EM, VanderElst M, Stassen LP, Schepers T (2012) Discriminating Between Simple and Perforated Appendicitis. J Surg Res 176 79-83.

18. Hallan S, Asberg A (1997) The Accuracy of C-Reactive Protein in Diagnosing Acute Appendicitis. Scand J Clin Lab Invest 57: 373-380.

19. Thompson MM, Underwood MJ, Dookeran KA (1992) Role of Sequential Leucocyte Counts and C-Reactive Protein Measurements in Acute Appendicitis. Br J Surg 79: 822-824.

20. Han PW, Ching YL, Chang CF, Chang YJ, Huang CY (2005) Predictive Value of C-Reactive Protein at Different Cutoff Levels in Acute Appendicitis. Am J Emerg Med 23: 449-453

21. Miller TA, Bass BL, Fabri PJ et al. Modern Surgical Care - Physiologic Foundations and Clinical Applications (3rdedn.) The Immune System and the Immuno compromised Patient, Informa Healthcare, New York.

22. Jangjoo A, Varasteh AR, Bahar MM, Meibodi NT, Aliakbarian M, et al. (2011) Is C-Reactive Protein Helpful for Early Diagnosis of Acute Appendicitis? Acta Chir Belg 111: 219-222.

23. Alberts B, Johnson A, Lewis J et al. (2002) Molecular Biology of the Cell (4thedn.) The Lives and Deaths of Cells in Tissues, Garland Science, New York.

24. Barreto SG, Travers E, Mackillop C, Tiong L, Lorimer M, et al. (2010) Acute Perforated Appendicitis : An Analysis of Risk Factors to Guide Surgical Decision Making. Indian J Med Sci 64: 58-65. 
Citation: Tucker A, Sloan K, Gartsin I, Verghis R (2015) White Cell Counts, CRP and Appendicitis - Is There A Role for Pre-Operative Blood Tests? A Cohort Study. J Health Med Informat 6: 185. doi:10.4172/2157-7420.1000185

Page 6 of 6

25. Okamoto T, Sano K, Ogasahara K (2006) Receiver-Operating Characteristic Analyses of Leukocyte Counts and Serum C-Reactive Protein Levels in Children with Advanced Appendicitis. Surg Today 36: 515-518.

26. Sulberg D, Chromik AM, Kersting S, Meurer K, Tannapfel A, et al. (2009) Appendicitis in the Elderly. CRP Value as Decision Support for Diagnostic Laparoscopy. Chirurg 80: 608-614.
27. Vaughan-SP, Richardson C, Lewis M (2011) White Cell Count and C-Reactive Protein Measurement in Patients with Possible Appendicitis. Ann R Coll Surg Engl 93: 183. 